\title{
DESCRIÇÃO DE UMA NOVA ESPÉCIE DE Hyalella SMITH, 1874 (CRUSTACEA, AMPHIPODA, HYALELLIDAE) PARA A REGIÃO CENTRAL DE SANTA CATARINA
}

\author{
Reis, G.O. ${ }^{1, *}$ \& Bueno, A.A.P. ${ }^{1}$ \\ ${ }_{1}^{1}$ Universidade Federal de Lavras (UFLA), Campus Lavras, Laboratório de Carcinologia. \\ *Autor correspondente: goliveirareis@yahoo.com.br
}

\begin{abstract}
Os crustáceos do gênero Hyalella são animais endêmicos do continente americano. São descritas 73 espécies no total, sendo 64 para a América do Sul e 28 para o Brasil. No trabalho foi descrita uma nova espécie de Hyalella Smith, 1874, para a região central do estado de Santa Catarina. Com localidade tipo um alagado do Ribeirão Antônio, no interior do município de Palmeira, pertencente à Bacia Hidrográfica do Rio Canoas. Os espécimes foram coletados com o auxílio de uma rede de mão e conservados em etanol $70 \%$. O preparo de lâminas se iniciou com machos e fêmea sendo colocados em corante Vermelho Congo, durante 12 a 24 horas. Após a coloração, os apêndices foram separados, colocados em lâminas contendo Hoyer e, cobertas com lamínulas. Para uma secagem mais rápida, utilizou-se uma estufa por 24 a 48 horas. Fotos foram realizadas com auxílio de um microscópio com câmera acoplada e do software Carl Zeiss AxioVision. Para a confecção dos desenhos foi utilizado o software CorelDraw X7. Hyalella sp. n. se diferencia das demais espécies brasileiras por apresentar três setas paposas no artículo 4 da antena 2; setas paposerradas nas mandíbulas e maxilas; ausência de setas plumosas no maxilípodo; gnatópodo 1 com comb-scales no carpo, própodo e dáctilo; gnatópodo 2 com combscales no ísquio, carpo e própodo; palma maior que a margem posterior do própodo no gnatópodo 2; gnatópodos sem setas serradas e plumosas; seta curva no ramo interno do urópodo 1; três setas apicais no télson, com ausência de setas laterais. A descrição desta nova espécie fornece subsídio para que estudos ecológicos sejam realizados e, desta maneira, ocorra a conservação da espécie e do local que habita.
\end{abstract}

Palavras-chave: taxonomia, crustáceos, Bacia do Rio Canoas. 